\title{
The Effectiveness of Likes Method in Improving Reading Skills of Orang Asli Students
}

\author{
Norwaliza Abdul Wahab ${ }^{1}$, Ridzuan Jaafar ${ }^{1}$, Ramlee Mustapha ${ }^{2}$, Arasinah $\mathrm{Kamis}^{2}$, Haryanti Mohd Affandi ${ }^{3}$ \\ ${ }^{1}$ Faculty Human Development, Sultan Idris Education University, Perak \\ ${ }^{2}$ Faculty of Technical and Vocational, Sultan Idris Education University, Perak \\ ${ }^{3}$ Faculty of Education, National University of Malaysia \\ Correspondence: Norwaliza Abdul Wahab, Faculty of Human Development, Sultan Idris Education University, \\ Perak. E-mail: norwaliza@fppm.upsi.edu.my
}

Received: March 14, 2017

Accepted: March 30, 2017 Online Published: May 31, 2017

doi:10.5539/ass.v13n6p74

URL: https://doi.org/10.5539/ass.v13n6p74

\begin{abstract}
This study aims to examine the effectiveness of the LIKES method in teaching KVKV (consonant, vowel, consonant, vowel) syllables in bahasa Melayu (Malay language) among Orang Asli students in primary schools. This research was conducted in two Orang Asli schools consisting of pupils aged 8 to 10 years as the subjects of the study. Quasi-experimental methods were used to determine the effectiveness of the LIKES method. Assessments were carried out for eight weeks including diagnostic tests as well as pre and post tests. The results showed significant differences in the reading skills of the control group (CG) and experimental group (EG). The study found that the reading skills according to gender was not a significant. Results from the observations showed the Orang Asli students are more focused and enjoyed to learn while using LIKES method in class. The findings clearly show that the LIKES method are suitable to be given to Orang Asli students, or students in remedial classes to improve the skills of reading especially KVKV syllables in bahasa Melayu.
\end{abstract}

Keywords: LIKES method, reading skills, Orang Asli, indigenous pedagogy, Malaysia

\section{Introduction}

Language skills are fundamental in the process of teaching and learning in the various disciplines in schools (Abdul Rasid, 2011). If the literacy of reading and writing is not obtained and mastered properly, the child's risk of failure in the school system will increase (Whitehurst \& Lonigan, 2001). Literacy education, especially in bahasa Melayu as the main subject taught in schools throughout the country (Malaysia) should be further strengthened in line with its status as an official language and national language of the country as mentioned in Article 152 of the Constitution. Reading is a cornerstone of success not just in schools but throughout life. Through reading, we acquire new ideas and knowledge, obtain needed information, relax the minds, and improve our command of language and vocabulary (Inderjit, 2014). Bahasa Melayu also is a main language to teach other subjects such as science and mathematic.

However, in Malaysia, the Orang Asli community is a minority group that is still far behind and have a higher dropout rate in education compared with other races. This covers all levels of education starting from preschool to higher education institutions. Statistics from Department of Orang Asli (2010) indicated that 1,322 of the 3,853 Orang Asli students who graduated in year six failed to proceed to form one. Only $30 \%$ of Orang Asli students completed their secondary school education, which is less than half of the national average (Ministry of Education, 2012). This clearly shows the achievement of Orang Asli students are yet to be proud of.

There are several factors that influence academic achievement among Orang Asli students. Among them is a low level of awareness of Orang Asli parents have towards their children's education. The parents of Orang Asli students are viewed to be less supportive and lack guidance in their children's academics. This is because the parents' education level itself is very low and they cannot be a role-model to their children. Children are more influenced by parents because a number of time children stay at home is longer than in school (Johari, 2007). In addition, the location of the Orang Asli settlements also become one of the main factors affecting Orang Asli dropout from the education system. According to the Department of Orang Asli (JAKOA), 31.7\% of indigenous villages are located in remote areas, $61.45 \%$ settlements are located in outskirts of the city while $1.38 \%$ is in the 
city (Zainal Abidin, 2004). Transportation services are very limited and in some areas, there are no modes of transportation for the Orang Asli students to go to school. This makes it complicated for them to get an education (Mazda Marjuki, 2009).

The downside to not mastering reading and writing makes students feel inferior and self-discipline will deteriorate. These students hold on the thought that by going against the norm in school, it will pull the interests of teachers and friends. Humility due to continued failure led to the concept of low self-esteem. Aggressive behaviour, negative, childish and mope are indicators of serious emotional problems. This will affect their ability to master language skills more effectively (Abdul Rasid, 2011).

Learning to read is fundamental in the control of human cognitive and social environment (Yahya, Roselan and Naffi, 2009). Appropriate teaching methods should be practised by teachers in order for the process to master these skills can be applied easily and effectively especially on Orang Asli students. The focus of this study is to the literacy of Orang Asli students so that they are able to pronounce and read correctly and effectively in the early stages of schooling.

An appropriate method of reading needs to be used in accordance with the student's abilities and capabilities that can provide a positive impact on literacy. Therefore, this study was undertaken to see to the implementation of teaching methods that is appropriate for the students so that they can read simple words such as word KVKV (consonant-vowel-consonant-vowel) to attract students to speak and read more difficult words after they move up to level two later. Orang Asli students that are poor in reading and writing skills need a lot of practice to master reading. Therefore the study is to provide information about the use of LIKES method in the teaching and learning of Orang Asli students.

\subsection{Objectives of the Study}

- To evaluate the effectiveness of the LIKES method.

- To identify the gender differences in mastering reading skills amongOrang Asli students using LIKES methods.

- To identify interests, excitement and involvement of Orang Asli students when teachers use LIKES methods in the classroom.

\section{Background of the Study}

Syllable in a word was a fraction consisting of a vowel or consonant combinations. There were 11 patterns of syllables, namely $\mathrm{V}, \mathrm{VK}, \mathrm{KV}, \mathrm{KVK}, \mathrm{KKV}, \mathrm{KKVK}, \mathrm{VKK}, \mathrm{KVKK}, \mathrm{KKKV}$ and KKKVK. In this study, researchers used the words that contained syllables KVKV. Example of syllable KVKV was su+su, gi+gi, pi+pi, and ti+ti. LIKES method was an approach to teach students of Orang Asli who had trouble reading in bahasa Melayu. LIKES means [LIhat (see), KEnal (memorize) and Sebut (sound) in which the students were given a card bearing the words of KVKV. While they took a look at the card, the students were taught to spell out the words until they could memorize the KVKV words.

Gooacre (2012) stated, in understanding the process of reading the teachers should identify the problems faced by the students first and help overcome these problems. Tamam et. al (2011) confirmed that the dominance of the Malay language subject could not lead the Orang Asli students to master other subjects. Early childhood literacy is very important in the development of reading skills. Slavin (2012) believed children should enter school with the knowledge to read because with this knowledge, the student can attend formal sessions of the teaching and learning in school. Malloy et al. (2010) suggested reading skills influenced by the attitudes and interest. Students who could not read did not show an interest in reading and a desire to read even less.

According Masitah Samsi (2011), exposure to reading at an early stage is very important to help overcome reading problems in formal education. Children have a desire to learn, learn, explore, experiment and research. This statement is consistent with the study by Abdul Rasid Jamian (2011) which stated that reading is to increase knowledge and the basis for the formation of self. Students need to think, feel and imagine what you read.

\section{Methodology}

The study includes both quantitative and qualitative research. Quantitative research study means research conducted by collecting data from respondents by providing pre-test and post-test. Before testing, screening tests have been carried out for a week and tested by using a diagnostic test to ensure equality reading level samples.Both groups were given a pre-test and post-test in order to determine the level of improvement of their reading comprehension skills. After sample tests were conducted, results tests were examined using independent t-test. A quasi-experimental design was used to replace the design of a pure experiment when in the process of 
selecting respondents, random distribution can not be performed by researchers (Chua, 2006). This method is commonly used by researchers in psychology, sociology and education (Neuman \& Dickson, 2000). The design of the pre-post test groups that are disproportionate is the most popular design used in the study of efficacy in this education study. Research design form described in Table 1.

Table 1. Quasi Experimental Research Design

\begin{tabular}{llll}
\hline Experiment Group (EG) & Pre-Test & $\mathrm{X}^{*}$ & Post-Test \\
\hline Controlled Group (CG) & Pre-Test & $\mathrm{Y}^{*}$ & Post-Test \\
\hline
\end{tabular}

The independent variable in this study is a teaching approach that will be used for the experimental group (EG) and the control group (CG). The dependent variables are the achievement in reading skills of students. The EG was taught to master the skills of pronouncing KVKV words using LIKES, while the CG using conventional approaches. Both groups were given a pre-test and post-test before and after the study. Although the sample selection was not done randomly but researchers have identified that the samples of the two groups that have the ability to achieve matching based diagnostic tests that are run by the school.

The qualitative aspect of form based on teachers' observation towards research sample during teaching and learning in the classroom. The researcher provides a checklist during the observation particularly matters involving students when the T\&L is running. This data is used as data support for the quantitative data presented in this research report. Observation method is a method which is an alternative that is in the collection of information or data collection besides interviews. Observation requires researchers to observe the students' own reactions. This method allows researchers to better understand the real situation to be described.

\subsection{Samples}

Research sample are Orang Asli students in Level 1 from Mualim, Perak. Study samples consisted of 16 Orang Asli students ( 8 boys and 8 girls) from 2 rural Orang Asli primary schools aged from 10 to 12 years old. A sample survey in each schools will represent the EG and another school will represent the CG. Each school represents a study group so that the instruction given to a group does not affect the other group. Besides that, the low number of Orang Asli students made it difficult to get more samples. Two teachers from bahasa Melayu options and who had been teaching for 3 years will be the facilitator for the both EG and CG groups.

\subsection{Procedures}

The study was conducted for 10 weeks during school hours. On the $1^{\text {st }}$ week the both groups were given a pre-test in the form of an oral and reading exam that consists of KVKV words based on images given. Test conducted by individual and group not more than 3 students are asked to sit next to the facilitator. Starting from $2^{\text {nd }}$ until the $9^{\text {th }}$ week the both groups were taught using thedaily lesson plans and teaching aids prepared by the researcher for the convenience of teachers implementing LIKES method on an experimental basis. Teaching aids is only supplied to the EG. Mean while the CG were using the existing teaching aids in the school. Teaching lessons and aids are supplied thematically different from the first week until the 8th week. Themes that have been used are KVKV words according to the type of limb, fruit, objects, food, animals, beverages, vegetables and numbers. Rancangan Pelajaran Harian (RPH) provided to the CG is the conventional teaching while the RPH provided to the EG would be according LIKES method.

EG were taught using LIKES method while the CG was taught by using conventional approaches. Each week the subject is taught once a week for 60 minutes by using LIKES. Tests were run in the $5^{\text {th }}$ and the $10^{\text {th }}$ weeks. The evaluation was made on the answers of students and checked by a weighting which was provided. Results of pre and post test were analysed by comparing the mean of students' achievement for the both groups. During the experiment conducted from the $2^{\text {nd }}$ to the $10^{\text {th }}$ week, the teachers for the EG samples were carefully monitored for students who are involved with the study.

Table 2. Pre test Reading skills according to groups

\begin{tabular}{ccccc}
\hline Group & Mean & Standard Deviation & T-Value & Significant Level \\
\hline Controlled & 27 & 5.42 & 1.617 & .150 \\
Experiment & 32.5 & 4.56 & & \\
\hline
\end{tabular}




\subsection{Data Analysis}

The data obtained through this study were analysed using the Statistical Package for the Social Sciences (SPSS) in numeracy table form. The data from the diagnostics test scores, pre and post were analysed using independent t-test. To strengthen research findings, the qualitative analysis also had been made for the data obtained through the checklist.

\section{Findings}

H01: Reading skills in pre-test is the same between CG and EG.

Table 2. Reading skills in pretest according to group type

\begin{tabular}{ccccc}
\hline Group & Mean & Standard Deviation & T-Value & Significant Level \\
\hline Controlled & 45 & 6.61 & 7.49 & .001 \\
Experiment & 75 & 4.08 & & \\
\hline
\end{tabular}

Pre and post test were done to determine the effectiveness of the LIKES method to the EG and the comparison with a CG using conventional methods. Based on Table 2, it was found that there were no significant differences in the percentage of achievement in the early reading test according to the type of group $(t=1.617 ; p>0.05)$. Therefore, the null hypothesis (H01) is accepted. Therefore, there were no significant differences in the results of the initial test read between the CG and EG students. Initial reading test results in the pre-test students CG (mean $=27$ ) is the same as the results of the EG students (mean $=32.5$ ).

H02: Reading skills in the post-test were similar between the students of the both groups

It was found that there were significant differences in the percentage of reading post-test according to the type of group ( $\mathrm{t}=7: 49 ; \mathrm{p}<0.05$ ). Therefore, the null hypothesis $(\mathrm{H} 02)$ is declined. After reading the test results of students from the CG $($ mean $=45)$ it was lower than the reading test results of the students from the EG (mean = 75).

H03: Reading skill in the pre-test is similar between boys and girls.

Table 4. Reading skill in pre test according to gender

\begin{tabular}{ccccc}
\hline Gender & Mean & Standard Deviation & T-value & Significant Value \\
\hline Male & 29.17 & 5.63 & .199 & .848 \\
Female & 30 & 6.61 & & \\
\hline
\end{tabular}

Based on Table 4, it was found that the achievement of male and female in terms of percentage of average achievement in reading pre-test showed no significant difference in the scores $=.199 ; p>0.05$. Reading results in a pre-test for the male with a mean $=29.17$ and female with mean $=30$ is the same. Therefore $\mathrm{H} 03$ is accepted.

H04: Reading skills in the post-test were similar between male and female

Table 5. Reading Skills in Post Test According to gender

\begin{tabular}{ccccc}
\hline Gender & Mean & Standard Deviation & T-value & Significant Level \\
\hline Male & 77.5 & 3.54 & 1.099 & .314 \\
Females & 83.33 & 11.55 & & \\
\hline
\end{tabular}

Table 5 shows that there was no significant difference in the reading test results (Post-test) between male and female $(\mathrm{t}=1.099 ; \mathrm{p}>0.05)$. This applies even if the mean value was found to be different between male (mean = $77.5)$ and female $($ mean $=83.33)$. This means that male and female have the same level in reading because there is no difference in the gender of the post-test reading. The hypothesis H04 is accepted. 


\subsection{Observation Checklist}

The basic skills of reading and the students behaviour during the process of teaching and learning were observed. These observations check list were marked as YES or NO. The basic skills are included in identifying vowels, consonants, identify the picture and the image of the word. Majority of the Orang Asli students are unabled to read because they were confused between the sound of syllables and a letter. According to Nor Laila Kuslan (2014), these students always confused between 'bi' with 'b'; 'si' with 'c'; 'di' with'; 'I' with 'g'; 'ai' with 'i'; 'pi' with 'p', 'r' with 'ar', 'ti' with 't' and 'u' with 'yu' For example, 'u 'as yu', meanwhile 'ulu' pronounced as' yu + lu '. However, these students pronounced the words 'ulu' correctly after they learned the technique using the LIKES method. This shows that Orang Asli students who are weak in their command of bahasa Melayu face a lot of confusion between spelling and pronunciation. Through LIKES methods it will encourage students to read the syllable correctly and easily.

To ensure the Orang Asli students to spell out the letters one by one is difficult because of the relatively poor memory of the students in memorizing what they have learned. Spelling methods are conventionally difficult for these students. In the case study by Nor Laila Kuslan (2014), she had found some disciples to spell 'baju' (clothes) but through this LIKES methods, the Orang Asli students were more proactive and easily remember what is taught. This is because the Orang Asli students do not have to make spelling activity but continue to sound the syllables as 'ba'+ 'ju'.

The students in EG also had a good and satisfactory behaviour during teaching and learning process using LIKES method. The Orang Asli students were found to be more focused. The Orang Asli students also were motivated to learn and seem more interested in mastering the Malay language. They were actively participating in the class activities. Besides that, negative behaviours such as making noise and disturbing other students and truancy also do not occur among group of students in the EG. During the observation, the students in the EG were more interested and excited to be involved in the teaching and learning process. According to Shazila et al. (2012), the most important implication of this study is the positive attitudes towards reading for shown by experimental subjects. This newly developed interest in reading bahasa Melayu materials outside class hours could developed students into becoming a life-long reader. The EG also showed an enthusiasm as they always wanted to read using KVKV words. Usage of optimal teaching aids in learning can meaningfully impact the students in mastering the language. It can also leave a positive impression in the disciples (Abdul Jalil Othman et al., 2011). Presentation slides which are also used in LIKES method is a good alternative to build an effective communication between teachers and students (Mohammed Hasan, 2000).

\section{Discussion and Suggestions}

According to the information presented to the researcher during a conversation with the headmaster of the Orang Asli schools there are three main factors of why the students like to go to school. It is known as $3 \mathrm{M}$ namely Makan (eat), Muzik (music) and Main (play). Therefore the LIKES methods which also include the element of playing in the classroom have attracted the interest of Orang Asli students to learn and improve their reading proficiency on KVKV words. This was also agreed by previous researchers. Nur Hanani (2004) stated that the use of induction set which attract the interests of students will make students more active in the learning process. The willingness of the students to concentrate on teaching and learning activities have increased the percentage of marks they scored in KVKV reading after LIKES methods were used significantly affect the reading test.

The findings in the post-test also showed that Orang Asli students regardless of gender were seen to have the same creativity growth in their areas and this can be associated with a previous study by Rathakrishnan and Lian (2014) that says sex does not affect children's creativity. Because creativity is strongly related to children's learning, particularly through pictures and letters, the researchers agreed that the absence of significant difference between the sexes in creativity contributes to equality of reading abilities among Orang Asli students either before or after being exposed to the LIKES method. Creativity is strongly related to education (Mohd Azhar Abd Hamid et al., 2003). Creativity is in fact owned by any individual but should be developed in a suitable situation and the right environment to flourish from childhood (Anna Craft, 2005; Mohamad Mohsin, Mohamad Said dan Nasruddin, 2008).

Some of the proposals which it deemed necessary to improve the performance of teaching and learning potential of Orang Asli students to improve reading and writing skills of primary school students outside should be emphasised seriously so that students can master it. Teaching bahasa Melayu should be presented in a more appealing approach to a diversity of teaching materials and teaching methods that are attractive and are able to expand the capacity of reading and writing skills of students. Diversified teaching methods can attract students to not get bored during the process of learning in the classroom. Furthermore, Orang Asli students are easily bored, 
especially when they are not interested in focusing the subject.

The use of interesting teaching aids in accordance with the level of cognitive development of students 'ability to cultivate students' interest and motivation to continue learning. Teaching aids should be used to the maximum in order to produce meaningful learning. According to Mohammed Hasan (2000), the use of the media is to facilitate teachers and students to interact or a two-way communication that can attract the recipients to respond. School administrators also need to conduct initiatives such as remedial classes or extra classes to help students who have trouble reading and writing. This effort should be continuous so that the results can be seen consistently.

Seminars and in-service courses should be given to teachers who teach in schools with Orang Asli by providing information and input about the special needs of Orang Asli students who did not master the skills of reading and writing. It can change the perception of teachers so that they are more positive that Orang Asli students also have the potential to succeed just like students from mainstream schools. Furthermore, patience and perseverance are important for teachers to help Orang Asli students until they success. It can be implemented if the MOE can conduct more specialised courses for teachers involved in the problems of reading and writing skills. Besides that the publishingofappropriate modules that contain appropriate teaching methods for the needs of Orang Asli students to improve their reading and writing skills. As stated by Inderjit (2014), reading not only increases our knowledge, but it also builds maturity and character, sharpens our thinking, and widens our awareness in social, economic, political, and environmental.

In addition, teachers will get the idea to try out the new approach to achieving the objectives of teaching and improve the academic performances of Orang Asli students. The results can also raise awareness of teachers about the importance of teaching and learning, especially in reading. It will help teachers who teach Level 1studentsin primary schools to improve the quality of teaching and also help teachers plan their teaching strategies more carefully. As stated by Norwaliza and Ramlee (2015) in order to attract Orang Asli students to immerse in the teaching and learning, they need to diversify the existing approach.

\section{Conclusion}

In conclusion, this study may provide insight into the use of LIKES method in terms of improving the skills of speaking and reading proficiency among Orang Asli students. Orang Asli students were more interested to participate in the teaching and learning process. Mean while in the classrooms, the teachers could diversify their teaching methods to be more fun and meaningful (Norwaliza \& Ramlee, 2015). This method aslo provides an alternative to the teachers who teach the Malay language to Orang Asli students. Therefore, the LIKES method represents a new alternative in solving the problem of Orang Asli students who cannot read. The results of the study will also be used to help teachers improve their knowledge and understanding of how to develop reading skills among Orang Asli students at the primary level. The teachers will be given an idea of the diversity of teaching methods that should be emphasised in the classroom. Teachers will be more confident in carrying out the teaching and learning $(T \& L)$ in the classroom. Finally, the results of this study can be beneficial to not only Orang Asli students but to other mainstream students who have trouble mastering reading skills effectively especially in bahasa Melayu.

\section{Acknowledgements}

The first author acknowledges the cooperation of the research participants and thanks Research Management and Research Centre (Research Code: 2015-0143-106-01), Sultan Idris Education University, for the Grant that partially supports this study.

\section{References}

Abdul Jalil Othman, Normarini Norzan, Ghazali Dausalam dan Saedah Siraj. (2011). Cabaran Guru Program Linus dalam Pengajaran dan Pembelajaran Bahasa. Masalah Pendidikan, 34, 2011.

Abdul Rasid Jamian. (2011). Permasalahan kemahiran membaca dan menulis bahasa Melayu murid-murid sekolah rendah di luar bandar. Jurnal Pendidikan Bahasa Melayu, 1(1), 1-12.

Anna C. (2005). Creativity in schools: Tensions and dilemmas. New York: Routledge.Chua Yan Piaw (2006). Kaedah dan Statistik Penyelidikan: Kaedah Pendidikan. Kuala Lumpur: McGraw Hill.

Department of Orang Asli (JAKOA). 2010. Program jabatan. http/www.jheoa.my [27 April 2016].

Gooacre, E. J. (2012). Children and Leraning to Read. London \& New York: Routledge, Taylor \& Francis Group.

Inderjit, S. (2014). Reading Trends and Improving Reading Skills among Students in Malaysia. International 
Journal of Research in Social Sciences, 3(5).

Johari T. (2007). Pengaruh Gaya Keibubapaan Terhadap Pencapaian Akademik Kanak-kanak (Wacana Pengajian Umum, Universiti Kebangsaan Malaysia, 2007)

Kementerian Pelajaran Malaysia. (2012). Pelan Pembangunan Pendidikan Malaysia2013-2020. Kuala Lumpur.

Malloy. J. A, Marinak B. A, \& Gambreall, L.B. (2010). Essential Reading on Motivation. USA: International Reading Association, Inc.

Mazdi Marzuki (2009). Situasi pilihan mod pengangkutan pelajar Sekolah Menengah: Kajian di Daerah Hulu Langat, Selangor. (PhD dissertation). Tidak Diterbitkan. Jabatan Geografi, Universiti Malaya.

Mohamad Mohsin, Mohamad Said dan Nasruddin Yunos. (2008). Peranan Guru dalam Memupuk Kreativiti Pelajar. Jurnal Pengajian Umum, 9(1), 57-71.

Mohd Azhar Abd Hamid. (2004). Kreativiti: Konsep, Teori dan Praktis. Johor: Penerbit UTM.

Muhamad Hassan Abdul Rahman. (2000). Media pengajaran: Penghasilanbahan pengajaran berkesan. Serdang: Penerbit Universiti Putra Malaysia.

Neuman, S. \& Dickinson, D. 2000. (Eds.). Handbook of early literacy research, 11-30. New York: Guilford

Nor Laila Kuslan. (2014). Aktiviti Pemulihan Bacaan di Sebuah Sekolah Rendah:Satu Kajian Kes. Tesis Ijazah Doktor Falsafah (Pendidikan). Universiti Malaya

Norwaliza Abdul Wahab and Ramlee Mustapha. (2015). Reflections on Pedagogical and Curriculum Implementation at Orang Asli Schools in Pahang. Procedia-Social and Behavioral Sciences, 172, 442-448

Nur Hanani Ab. Hamid (2004). Faktor-faktor yang Mempengaruhi Pembelajaran Pelajar 4 Sarjana Muda Sains serta Pendidikan (SAINS) dalam Mata Pelajaran Sains Mengikut Etnik. Tesis Sarjana. Universiti Teknologi Malaysia.

Rathakrishnan, B. \& Lian, I. (2014). Perbezaan Kreativiti Berdasarkan Jantina Pelajar Tingkatan Empat Di Kota Kinabalu Sabah. ISBN : 978-967-0582-32-0

Shazila Abdullah, Puteri Rohani Megat Abdul Rahim, Roszainora Setia, Razita Mohamad, Norliana Ghazali, Elangkeeran Sabapathy, Gopala Krishnan Sekharan Nair, Mohan K. Muniandy, Ramachandran Theethappan, Wan Aida Wan Hassan4 \& Nor Syamimi Iliani Che Hassan. (2012). Reading for Pleasure as a Means of Improving Reading Comprehension Skills. Asian Social Science, 8(13).

Slavin, R. E. (2012). Educational psycology: Theory into practice (10th Ed.). Boston: Allyn \& Bacon.

Tamam Timbang, Zamri Mahamod, Nik Mohd Rahimi Nik Yusoff \& Jamaludin Badusah. (2010). Masalah membaca murid-murid sekolah rendah di Brunei Darussalam: Satu Kajian Kes. Jurnal Pendidikan Malaysia, 35(2), 77-85.

Utusan Malaysia. (2007). 3.1 juta murid gagal kuasai kemahiran 3M. http://www.utusan.com.my/ utusan/arkib.asp? $y=2007 \& \mathrm{dt}=1211 \&$ pub=utusan_malaysia\&sec=parlimen\&pg=pa_01.htm\&arc=hive

Whitehurst, G. J. \& Lonigan, C. (2001). Emergent literacy: Development from prereaders to readers. Dlm. S. Neuman \& D. Dickinson (Eds.).Handbook of early literacy research (pp. 11-30). New York: Guilford.

Wilson, James W., Rita D. Roberts. (2006). Summary of Convective Storm Initiation and Evolution during IHOP: Observational and Modeling Perspective. Mon. Wea. Rev., 134, $23-47$.

Yahya Othman, Roselan Baki \& Naffi Mat. (2009). Pemerkasaan pendidikan Bahasa Melayu: Teori ke praktik. Kuala Lumpur: Utusan Publication \& Distributors.

Zainal Abidin Hj Ali (2004). Jabatan Hal Ehwal Orang Asli: Peranan dalam bidang penyelidikan. Kertas Kerja dalam Seminar Sehari Tradisi Lisan Masyarakat Orang Asli. Anjuran Pusat Pengajian Bahasa, Kesusasteraan dan Kebudayaan Melayu. Fakulti Sains Sosial dan Kemanusiaan, Universiti Kebangsaan Malaysia. 8 September.

\section{Copyrights}

Copyright for this article is retained by the author(s), with first publication rights granted to the journal.

This is an open-access article distributed under the terms and conditions of the Creative Commons Attribution license (http://creativecommons.org/licenses/by/4.0/). 